\title{
Research on the Development Opportunities and Students' Employment of Higher Vocational Education Colleges in Guangdong-Hong Kong-Macao Greater Bay Area
}

\author{
Zhang Ruixue \\ School of Information Engineering, South China Business Trade College, Guangzhong, China \\ Email address: \\ 121503471@qq.com \\ To cite this article: \\ Zhang Ruixue. Research on the Development Opportunities and Students' Employment of Higher Vocational Education Colleges in \\ Guangdong-Hong Kong-Macao Greater Bay Area. Science Journal of Education. Vol. 8, No. 5, 2020, pp. 120-127. \\ doi: $10.11648 /$ j.sjedu.20200805.12
}

Received: July 5, 2020; Accepted: September 19, 2020; Published: September 28, 2020

\begin{abstract}
This paper expounds the development opportunities of higher vocational education institutions in Guangdong-Hong Kong-Macao Greater Bay Area and the necessity of accelerating the adjustment and improvement of teaching methods, based on the data analysis of auto maintenance industry, logistics transportation production, finance and the other fields of skilled personnel in this Area. Since the implementation of the Outline of Guangdong-Hong Kong-Macao Greater Bay Area Development Plan by the Central Committee of the Communist Party of China and the State Council, the newly registered similar industries in Guangdong-Hong Kong-Macao Greater Bay Area have increased dramatically, showing a substantial increase. On the one hand, it is found that some enterprises and employers are reduce the number of posts and personnel so as to reduce the input cost of human resources, and reduce unnecessary production links so as to avoid invalid production costs, so as to improve work efficiency. On the other hand, they are in urgent need of high-level technical and technical talents who can fight when they come. The graduates of higher vocational colleges were never favored by employers, and their orientation and direction were unclear. Compared with the graduation certificates of ordinary colleges and universities with the same major, they were "second-class certificates". In fact, the graduation certificates of higher vocational colleges are showed the characteristics of "practical certificates".
\end{abstract}

Keywords: Senior Technician, Skilled Talents, Employment of Higher Vocational College Students

\section{Introduction}

The contradiction between supply and demand between the employment market of graduates of higher vocational education and the employment market of graduates of ordinary higher education is different in direction (professional and academic). The former focuses on technology and skill, while the latter focuses on academic and theoretical, and there are common and overlapping problems in the "demand side" of the labor market. How to face the overall tightening of the employment situation of graduates of higher vocational colleges, we must analyze the current situation of difficult employment of college students. The following focuses on the analysis of the common and overlapping parts between higher vocational education graduates and ordinary higher education graduates [1] in the "demand side" of the labor market. Only in this way can we sum up a set of effective methods to promote the employment of higher vocational education graduates into a benign track.

\section{Four Common Points in the Employment of College Graduates in the Current Labor Market}

Because the number of college graduates exceeds the demand of the human market every year (the proportion between the number of fresh graduates and the number of jobs demanded by enterprises and institutions in that year is out of balance), the employers are more selective than the graduates seeking jobs, and the fresh graduates (ordinary universities and higher vocational colleges) have no advantage in employment. In the 
labor market where college graduates are "difficult to find jobs", employers also generally have the contradiction of "finding people difficult" and "worrying about employing people". The pillars and backbone of most enterprises and institutions are all college graduates from previous years. In social practice, the development and innovation of enterprises and institutions can not be separated from college students. However, most enterprises and institutions, especially those with the nature of enterprises, are still unwilling to accept fresh college graduates every year, because these college students do not have credible practical work experience, nor have the intuitive sense of social responsibility of employers, and cannot guarantee that they can immediately see economic benefits.

There is a big gap between supply and demand: the prominent contradiction between supply and demand of graduates is the main reason for the employment difficulties of college students recognized by the society in recent years, and one of the main reasons for the employment difficulties of college students is that they are not correct in working attitude after being hired by the employer, and the employer does not recognize them. [2]. In 2019, the data publicly displayed by the Ministry of Education was 8.34 million college graduates nationwide. However, the number of jobs increased by enterprises and institutions in 2019 was far less than the number and expected value increased by the suppliers (fresh graduates). This is also a problem that our country is constantly discussing the rationalization of college majors to meet the needs of society and the scientific regulation of college enrollment scale (quantity) must be organically combined to solve.

The media does not strictly control all kinds of talent recruitment information: invalid recruitment information is mixed, not authentic, and the number of effective recruitment information is reduced. In view of the rising contradiction between supply and demand of fresh graduates' employment, some enterprises have launched fake recruitment, which on the one hand gives "high" treatment conditions, and then collects fees in the name of training, lecture fees and various names, and on the other hand dismisses college students on the grounds of unqualified trial (which greatly hurts the confidence of fresh graduates in employment). With the appearance of false enterprises and "one-day companies" in the society, the practice of "flying all over the sky" of college students' employment recruitment information proves that students get less real and effective information, which makes it difficult for college students to find jobs.

Students lack effective social practice ability training during school, and the teaching phenomenon of "more professors and less technicians" generally exists in schools. The biggest difficulty encountered by college students in job hunting is "lack of practical work experience". China's education system has trained talents according to the "consistent system" model for many years, and the specialty setting is out of touch with the social needs, and does not pay attention to the cultivation of practical ability. Although college students have professional knowledge, what they lack is practical ability, etiquette and legal thinking. Professors in universities are only responsible for imparting professional knowledge, but they lack hands-on ability like "technicians".

\section{Employment of Higher Vocational College Graduates and Current Situation of Human Market}

Through the analysis of A, B, C, D and four points above, the employment situation of higher vocational college graduates is facing the same employment pressure as that of ordinary college graduates. The employment of graduates has become an important social problem for the sustainable and healthy development of higher vocational education. How to help students in higher vocational colleges establish a correct view of "workplace" and expand their employment channels, the survival and development of higher vocational colleges are closely related to the recruitment and employment departments, and the current jobs cannot meet the employment needs of graduates from higher vocational colleges. The employment market of oversupply leads to the unfounded comparison of education, degree and major between graduates of higher vocational colleges and graduates of general higher education by the labor market and employers. In some enterprises and institutions, employers "artificially set" academic qualifications to compare with each other during job recruitment, and the labor market and employers arbitrarily raise academic qualifications, degrees and professional requirements without any basis, which greatly wastes national higher education resources.

The above chaos has caused a large number of graduates of higher vocational colleges to be rejected by employers, which has caused psychological obstacles to the employment of graduates of higher vocational colleges and objectively undermined their employment confidence. The employment ideal is "full" and the actual employment is "skinny", which causes the graduates of higher vocational colleges not to want to have a job. Most of the graduates of higher vocational colleges have idealized employment concepts. They are full of bright hopes for the post after employment, and have lofty ideals and ambitions. Some graduates can't evaluate themselves realistically. "If you look high, you just don't do it." You don't have a clear understanding of the current situation of employment tension in the labor market, and you don't realize the "market" phenomenon that labor supply exceeds demand. You imagine more jobs in the employment "market" than "objective existence". It has caused the phenomenon that people don't want to have jobs. The gap between practical ability and job demand is another factor that makes it difficult for graduates of higher vocational colleges to find jobs.

Employers generally require graduates to "fight when they recruit" and need talents with strong hands-on ability. The representative enterprises in Guangdong-Hong Kong-Macao Greater Bay Area have a "common bottom line" ranging from "the same day" to "three days" for the newly recruited 
employees, which directly indicates that the enterprises need talents with high skills and strong hands-on ability (technical and skilled). To sum up, these are the strengths of graduates from higher vocational colleges, and also the purpose of the country to intensify higher vocational education [3]. After the State Council issued the Outline of Guangdong-Hong Kong-Macao Greater Bay Area Development Plan, many large and medium-sized enterprises poured into the Bay Area. These enterprises have a strategic development vision, and they have seen many good policies in the Bay Area, especially investment policies and talent introduction policies. Once these enterprises enter the "Bay Area", apart from infrastructure construction, the first consideration is to introduce high-tech and high-skilled compound talents. The demand of these enterprises for talents with high technology, high skills and strong hands-on ability, especially for graduates from higher vocational colleges, will definitely increase. In this paper, Greater Bay Area is strictly in accordance with the "Bay Area Scope" in the "Bay Area Plan" issued by the Central Committee of the Communist Party of China and the State Council, which consists of two districts and nine cities (Hong Kong Special Administrative Region, Macao Special Administrative Region, Guangzhou, Shenzhen, Zhuhai, Foshan, Huizhou, Dongguan, Zhongshan, Jiangmen and Zhaoqing), so as to ensure guiding significance for the development opportunities and strategies of higher vocational education institutions in Guangdong-Hong Kong-Macao Greater Bay Area.

In order to let the students of higher vocational colleges in Greater Bay Area have a clear understanding of the current situation of employment shortage in the labor market and know more intuitively the standards and requirements of employing enterprises and units, we must seriously reflect on where the employment difficulties of higher vocational graduates appear. First of all, we should objectively admit that higher vocational education started late in mainland China. At present, there is still no complete teaching system, including the flexibility of specialized courses, teaching materials and teaching methods, the perfect enrollment system, the difference in teaching methods between higher vocational teachers and ordinary university teachers, and the students' learning methods. It is these reasons that have seriously affected the social phenomenon that graduates of higher vocational colleges find employment difficult.

\section{Current Situation of Curriculum and Teaching in Higher Vocational Colleges}

At present, the professional courses of higher vocational colleges still refer to those of ordinary colleges and universities, and some of them even imitate the setting of "being higher and higher", which is suspected of deviating from the original intention of setting up higher vocational colleges by the state and seriously inconsistent with the training of "skilled" talents urgently needed by social high-tech enterprises, especially the ever-changing "black technology".

Teaching materials and teaching methods are the basic guarantee of teaching, but the present situation is not optimistic. For example, teaching materials lack practicality and teaching methods lack vividness and intuition. We should learn from the anatomy class in medical colleges, that is, the number of teaching AIDS for assembling human body models is increased, and the number of teaching AIDS for wall charts is reduced. Here, we suggest that if we take the mechanical maintenance major as an example, we can reform the teaching model, do more models that can assemble and disassemble the starting machinery, and let the students disassemble it by themselves under the guidance of the teacher in class and reassemble it within the specified time, which will greatly improve the enthusiasm of students to participate in teaching, and also improve the enthusiasm of students to learn in fun. In this way, there will be no phenomenon that a small number of graduates majoring in mechanical repair in higher vocational colleges do not disassemble the automobile engine after working in an automobile 4S shop for one working day, which indirectly affects the impression of society on graduates of higher vocational colleges. The analysis of this phenomenon is because students lack practical teaching materials and teaching methods and hands-on practical classes during their schooling.

Students in higher vocational colleges generally have low academic performance in high school, and most of them are admitted to higher vocational colleges because the scores of college entrance examination do not reach the admission scores of ordinary colleges and universities. It is precisely for this reason that most students enrolled in higher vocational colleges cannot update their concepts in time, and mistakenly think that higher vocational colleges are "specialist classes" of ordinary colleges and universities. Therefore, the society, parents and teachers have the responsibility to make their sober people realize the great difference between ordinary colleges and higher vocational colleges, and let them know that they will be engaged in advanced technical work with strong practical ability in all walks of life in the future. With the emergence of "black technology", a new high-tech job with rapid transformation of processing methods and modules is in short supply, which cannot be undertaken without strong theoretical foundation and rich practical experience. The above viewpoints have been confirmed by the demand for high-tech jobs in medical equipment maintenance manufacturing, automobile maintenance manufacturing, refrigeration equipment maintenance manufacturing, leisure tourism service, logistics and transportation production, financial industry and the investigation report of this industry.

Take automobile maintenance service industry as an example; At present, there are only over 400,000 people engaged in automobile technical service and marketing in the whole country. The number of employees who graduated from maintenance service and marketing technical posts in higher vocational colleges is less than $10 \%$ of the employees, [4] which is in a "shrinking" state compared with the actual post demand. There are very few people with professional training, 
excellent technical service and marketing experience before taking up their posts, and at the same time, they have professional automobile marketing experience, and compound technical talents with special skills such as automobile marketing 、 technical service、 automobile credit、 automobile insurance and claims settlement used car trading [5] are very popular among employers. Unfortunately, such graduates of higher vocational colleges are in short supply and often appear "out of gear", and 3 million technicians are engaged in the above positions, but only about $26 \%$ of these 3 million people graduate The existing on-the-job senior technicians are older, and their knowledge update is relatively backward. $40 \%$ of the first-class workers and technicians only have junior high school education, which has seriously lagged behind the development of the automobile maintenance industry to high-tech. In view of this country's great attention, the training of automobile application technology professionals has been included in the "National Manufacturing and Modern Service Industry Skills Shortage Talent Training Project" [6]

\section{The Society's Understanding of Graduates from Higher Vocational Colleges Is Gradual}

Different regions and industries differ in the teaching between higher vocational colleges and ordinary higher education institutions, and the purpose of setting up higher vocational education institutions in China is quite different in the time of cognition and acceptance. Hong Kong and Macao recognized and accepted higher vocational colleges earlier (1975-1985), although the first vocational university was established in mainland China in 1980, the time of cognition and acceptance of higher vocational colleges lags behind (1980-2011) From this time, higher vocational colleges in mainland China have legal basis and operational guarantee. The cognition and acceptance of higher vocational colleges in China's inland have a long time span, which is directly related to the lag in the starting time of higher vocational colleges in China's inland areas compared with developed countries (regions). In addition, students and their parents have been influenced by traditional ordinary higher education for a long time, and employers have been influenced by traditional ordinary higher education for a long time. "They" generally believe that only when they are admitted to ordinary colleges and universities are "college students", and their diplomas are "second-class certificates". All of these are the important reasons why enterprises and employers lag behind in their cognition and acceptance of higher vocational colleges.

In the current society, there is a very abnormal phenomenon, in which employers and individual departments employ people only for their academic qualifications. In this abnormal atmosphere, the construction and development of higher vocational education colleges are seriously lagging behind, and the employment of graduates of higher vocational education colleges in the labor market is impacted by graduates of ordinary colleges and universities. This kind of impact comes from higher education institutions, and is also inseparable from the social labor market discrimination against students in higher vocational education institutions. In particular, students in higher vocational education institutions are promoted to ordinary colleges and universities after graduation, even if they are promoted to undergraduate courses in key universities, they will be admitted to master's degrees in key universities after graduation. When higher vocational education institutions with high academic qualifications have a "low starting point", they will still encounter social labor market discrimination, and some employers even openly ask for "first degree". The employer's over-emphasis on the first degree with low starting point aggravates the employment difficulty of graduates of higher vocational education. We strongly appeal here that local governments and educational administrative departments should formulate a set of laws and regulations to ensure that graduates of higher vocational colleges and ordinary colleges are not discriminated against in employment, so as to ensure that the social and human market cannot overemphasize the first degree and employers set up jobs on the grounds of academic qualifications unscientific. Only when employing people with "first degree" and entering a good atmosphere of employing people with "ability" can they begin to appear, and the wrong views of discriminating against graduates of higher vocational colleges will surely enter history.

Searching online according to which option is more needed by high-tech, high-skilled, hands-on employees and highly educated employees shows that all labor-intensive enterprises, especially technical jobs with strong hands-on ability, choose employees with high technology, high skills and strong hands-on ability. Taking IT enterprises as an example, the company boss and the personnel department manager discuss the problem of recruiting talents every day, but they still can't recruit employees who can solve the problem as soon as they take up their posts. The employees with weak hands-on ability walk like a lantern and come again and again, which makes the boss of IT enterprises break his brain. Excessive and excessive staff training expenditure is also a heart disease for enterprises. We find that graduates of higher vocational colleges must practice hard at ordinary times if they want to get high-paying jobs. Technology, improve their own hands-on ability, in this type of enterprise highly educated "gorgeous appearance" is actually not important. All of the above indicate that enterprises have realized the differences between academic, theoretical (ordinary colleges) and technical and skilled (higher vocational colleges), and they also hope to recruit technical talents with strong hands-on ability, so as to bring the greatest economic benefits to enterprises in technological innovation and technological transformation with the lowest labor cost. In such an environment, graduates of higher vocational colleges can work with peace of mind, enterprises and employers can rest assured, students in higher vocational colleges have confidence, and parents have less worries about employment.

Enterprise employers have their own rules for the time limit (days) for newly recruited employees to get familiar with their 
jobs. No matter the time limit (days) for newly recruited employees to get familiar with their jobs and start working in all kinds of enterprises has a very high bottom line. The repair departments and logistics enterprises of $4 \mathrm{~S}$ stores have higher requirements, and they all need the heads of the technical departments recruited to be skilled at their posts on the same day, and command their employees to operate efficiently to bring economic benefits to the enterprises. The requirement of working on the same day also fully reflects the higher requirements for higher vocational college graduates. Being familiar with work is also a bright spot for graduates of higher vocational colleges, so we must keep this bright spot.

There is a great demand for graduates of higher vocational education colleges in the graduation season every year. With the high labor cost of enterprises in recent years, the difference between graduate students, undergraduates and salaries has increased, and the division of labor has been refined, which makes the labor cost of enterprises increase. At present, there is a trend in enterprises that the employment of enterprises is more rational. From the angle of increasing revenue and reducing expenditure, the talents with knowledge, theory, high technology, high skills and strong practical ability are selected as "rational employment".

\section{The Best Time for Higher Vocational Colleges to Seek Development}

The Fortune Global 500 list is one of the important indicators in the industry to measure and compare the economic development between enterprises and countries. The list data released by Fortune released the latest data on the distribution changes of individual regions in the global economy. The newly added enterprises in Guangdong-Hong Kong-Macao Greater Bay Area are Cedar Holdings, China Merchants and China Taiping Insurance Group, with a total number of 20, an increase of 3 over last year, with an increase of $17.6 \%$. In this list of global concern, the number of Chinese companies on the list ranks second, reaching 120 this year. The distribution of enterprises in various industries is diversified. The 20 short-listed enterprises in Guangdong-Hong Kong-Macao Greater Bay Area are distributed in the Internet, communications, automobiles, household appliances, bulk commodities, insurance and finance, and real estate, mainly in the real economy. The innovation effect is obvious. Tencent, Country Garden, HUAWEI and Midea rank first among Chinese companies in the field of information and communication technology with the most obvious spillover effect of innovation benefits, and all four companies are located in Guangdong-Hong Kong-Macao Greater Bay Area. Tencent is the company with the highest profit margin (over $30 \%$ ) in Chinese mainland.

Although the construction of Guangdong-Hong Kong-Macao Greater Bay Area has brought development opportunities to higher vocational colleges, students in higher vocational colleges can't ignore the improvement of their comprehensive quality. If they don't improve their autonomous learning ability, they simply learn the professional knowledge taught by the school and don't learn other "extra-curricular" knowledge, resulting in low comprehensive quality and humanistic quality. Even if there is a suitable job in the labor market, and there is no real high skill, high technology and strong practical ability, it is still difficult for graduates of higher vocational colleges to take on the heavy responsibilities in their posts. The phenomenon that graduates of higher vocational colleges find it difficult to get a job will continue.

The effective way to improve the employment rate of graduates in higher vocational colleges is to do a good job in ideological education and patient and meticulous work, and to reverse the wrong idea of "not having a job". Changing the concept of choosing a job is the most important thing. The party and league organizations should routinely do ideological and political work for graduates, correctly guide their outlook on life, values and career choices, and abandon the wrong traditional employment outlook [7]. Advocating the first step from the grass-roots level, laying a good foundation for the "deep pile" at the grass-roots level, enriching the experience at the grass-roots level, and encouraging "employment first, then choosing a career". Support students to establish the concept of self-employment, a variety of flexible employment directions, and help students move toward society as soon as possible after graduation. Use the current development situation and employment policy of Guangdong-Hong Kong-Macao Greater Bay Area to guide graduates to look at employment expectations objectively [8], and use various media to publicize students' concept of "seeking development after employment first", so that they believe that only employment first can have a "platform", and with this platform, they can look for more and better development opportunities and channels. Colleges and universities themselves should be grounded in the curriculum system and teaching material system. After the publication of the Outline of Guangdong-Hong Kong-Macao Greater Bay Area Development Plan, the industrial structure, the scale of enterprise development, the emergence of new industries and the renewal of the original technology in the region will definitely be greatly adjusted. The curriculum and teaching materials of higher vocational colleges should be flexibly adjusted according to the economic construction in the region. Open up a variety of ways to cultivate talents, and innovate vocational education textbooks and teaching methods. Scientifically and objectively set up new majors and new courses to meet the needs of Guangdong-Hong Kong-Macao Greater Bay Area's construction, and form the dominant position of each major in the school in "Greater Bay Area". At the same time, in the teaching content of professional courses [9], the curriculum should be based on the employment needs of employers in enterprises, and the proportion of experimental and practical training courses should be appropriately increased. The professional scope is too narrow and the situation of "ungrounded" needs to be changed. The employment of graduates is related to the century-long plan of higher vocational colleges, and also to the survival and 
development of higher vocational colleges.

Higher vocational colleges should pay more attention to whether there are emerging science and technology industries in peacetime. For example, more and more "black technologies" appear one after another, because the existence of any science and technology, including "black technologies", is time-limited. Science and technology are constantly upgrading at a high speed, and the original technologies are constantly updated or even replaced by new technologies and "black technologies". Therefore, which higher vocational education colleges have started majors and courses in emerging industries first, this school is the winner, and graduates will have opportunities in employment. Higher vocational colleges should take the initiative to understand the employment dynamics of higher vocational graduates in the society, grasp the context of the employment market in real time, grasp the new situation encountered in the employment of graduates at any time, refine the scientific employment system of students, quantify the target responsibility mechanism of students' employment, and make unremitting efforts to guide the employment of graduates.

\section{Current Situation of Higher Vocational Colleges in Guangdong-Hong Kong-Macao Greater Bay Area}

Guangdong-Hong Kong-Macao Greater Bay Area includes Hong Kong Special Administrative Region, Macao Special Administrative Region and Guangzhou, Shenzhen, Zhuhai, Foshan, Huizhou, Dongguan, Zhongshan, Jiangmen and Zhaoqing (hereinafter referred to as the nine cities in the Pearl River Delta), with a total area of 56,000 square kilometers. At the end of 2017, the total population was about 70 million, equivalent to the total population of Jiangsu Province in China (72 million). The development scale and speed of infrastructure, investment and trade, financial services, science and technology education, leisure tourism, ecological environment protection, social services and other fields proposed in the Outline of Guangdong-Hong Kong-Macao Greater Bay Area Development Plan should be accelerated in an all-round way. In view of the analysis of the ratio between the population of Guangdong-Hong Kong-Macao Greater Bay Area and the number of students in higher vocational colleges and the total proportion between the population of Guangdong-Hong Kong-Macao Greater Bay Area and the number of higher vocational colleges, it is concluded that the development scale (quantity) and speed of higher vocational education colleges must be increased. There were 737,000 students in higher vocational colleges in Guangdong in 2017 [10], accounting for $94.97 \%$ of the total population of 70 million in Guangdong-Hong Kong-Macao Greater Bay Area (only one student in higher vocational colleges among about 95 people).

There are 88 higher vocational colleges registered by the Ministry of Education in Guangdong Province, excluding 17 non-Greater Bay Area colleges and 71 in Guangdong, Greater
Bay Area. According to the Vocational Training Council Ordinance (Cap. 1130), there are four vocational training institutions: IVE, HKDI, Thei, and SHAPE. According to the administrative regulations of Macao Special Administrative Region No. 26/2003 and the higher vocational education tourism college, Macao Jinghu Nursing College and Macao Security Forces Higher School (training police officers and fire officers), there are 3 above. By December 2018, there were 78 higher vocational colleges in Guangdong-Hong Kong-Macao Greater Bay Area certified by the Ministry of Education, Hong Kong Vocational Training Bureau and Macao Higher Education Bureau. Although the total number of higher vocational education institutions in Guangdong-Hong Kong-Macao Greater Bay Area is 78, the number of higher vocational education institutions only accounts for an average of 897,400 of the total population of 70 million in Guangdong-Hong Kong-Macao Greater Bay Area (about 900,000 people have only one higher vocational college). Such a proportion of population and higher vocational colleges will hardly play the role of "pile driver", "lubricant" and "accelerator" in the implementation of the Outline of Guangdong-Hong Kong-Macao Greater Bay Area Development Plan.

\section{Analysis of Employment Prospects of Graduates from Higher Vocational Colleges}

Catering industry: According to the latest data released by the National Bureau of Statistics on January 21, 2019, the revenue of catering industry in 2018 exceeded 4 trillion yuan. According to the research and analysis of Jiji. com, catering is the first industry with rapid growth of recruiters and posts, and southern cities such as Nanjing, Wuhan, Suzhou, Shenzhen, Guangzhou and Chengdu are the areas with the largest demand for higher vocational technical talents. Sales and customer service are more urgently needed for senior technical personnel positions. The recruitment of enterprises in new first-tier cities has gradually increased and surpassed that in first-tier cities. Hangzhou, Shanghai and Shenzhen are the top three cities in terms of demand for sales talents. Jinan, Shanghai and Shenzhen are the top three cities in terms of demand for customer service talents. Once again, the demand for basic service posts in big cities is greater than expected, and the new first-tier cities will gradually form the commanding heights of basic service personnel training [11].

Automobile maintenance industry: According to the "2019-2025 China Automobile Maintenance Industry in-depth Investigation and Investment Direction Research Report". This report accurately grasps the great changes in different periods of the industry, improves the awareness of business and investment risks, and reminds the industry to avoid detours in competition. It is also a scientific basis for strategic decision-making to ensure that competition and investment strategic decisions are not wrong, and has important reference value. By the end of 2018, the national car 
PARC had reached 240 million, an increase of 22.85 million or 10.51 percent over 2017 [12]. This kind of growth trend continues to develop, and the natural law of aging structure of vehicles will greatly promote the rapid development of China's automobile maintenance market [13], and also increase the demand for graduates of automobile maintenance major in higher vocational colleges. The rapid development of automobile maintenance field can not be separated from talents with high skills and strong hands-on ability, which will also be a good employment opportunity for graduates majoring in automobile maintenance in higher vocational education institutions.

Foreign trade: According to the monitoring statistics of the national foreign trade cargo throughput from January to August 2018 in China Report Hall, the national foreign trade cargo throughput in August 2018 was 312.02 million tons, up $1.1 \%$ year-on-year, and the national foreign trade cargo throughput from January to August 2018 was 2,486.78 million tons, up $2.6 \%$.

The following charts and data sources are quoted from the monthly data list of national foreign trade cargo throughput from January to August 2018 in China Report Hall:

Table 1. Monthly data of China's foreign trade cargo throughput from January to November 2018 [14].

\begin{tabular}{lllll}
\hline Time & $\begin{array}{l}\text { Current period value (Ten } \\
\text { thousand/ton) }\end{array}$ & $\begin{array}{l}\text { Cumulative value (Ten } \\
\text { thousand/ton) }\end{array}$ & Year-on-year growth (\%) & Cumulative growth (\%) \\
\hline January 2018 & 32008 & 32008 & 2.4 & 2.4 \\
February 2018 & 28011 & 60825 & 6.9 & -1.8 \\
March 2018 & 30162 & 90862 & 0.7 & 3.9 \\
April 2018 & 30524 & 121881 & 2.7 & 2.6 \\
May 2018 & 32078 & 154051 & 0.2 & 2.9 \\
June 2018 & 31539 & 186062 & 1.1 & 2.1 \\
July 2018 & 31129 & 217085 & -0.9 & -0.4 \\
August 2018 & 31202 & 248678 & 2.6 \\
September 2018 & 30499 & 279438 & 0.6 \\
October 2018 & 30424 & 310702 & 2.3 \\
November 2018 & 30617 & 341663 & & 2.3 \\
\hline
\end{tabular}

According to the data of catering industry, automobile maintenance industry and foreign trade cargo throughput, the number of jobs and the number of talents with high technology, high skills and strong hands-on ability in 2019 showed a sharp increase. Whether the talents have high comprehensive quality, whether they have enough experimental experience and solid practical training process before taking up their posts determines that the graduates of higher vocational education will not fall behind (get a smooth job) after the great historical opportunity comes. From now on, they should concentrate on studying professional courses, read more books of professional knowledge after class, improve their self-cultivation and expand their knowledge. Only in this way can the competitiveness of graduates of higher vocational education colleges in the human resources market be increased.

\section{Conclusion}

Higher vocational education institutions are an inseparable part of China's general higher education. Since 2012, the mainland of China began to pilot undergraduate majors in higher vocational education colleges, which has been well received by the society, students and parents of students. Higher vocational education includes two academic levels, namely, college [15] and undergraduate education. Students of higher vocational education will be awarded college and undergraduate diplomas with national recognized academic qualifications when they graduate, and enjoy all the treatment of college graduates [15]. However, society and some groups still hold incorrect traditional ideas about college graduates of higher vocational education, and think that only graduates of ordinary colleges and universities are college students. It is very important for this group to hold wrong ideas about graduates of higher vocational education colleges. We must never give up guiding their ideas correctly. We should let them know clearly through various channels that various talents are needed in the process of Guangdong-Hong Kong-Macao Greater Bay Area construction, especially the gap of graduates of higher vocational education colleges is very large. However, the current situation is not optimistic, and they are still "vulnerable groups" in the employment competition in the labor market. This paper focuses on the analysis and demonstration of how the graduates of higher vocational education colleges can improve their self-construction and competitiveness in the human market, see the current employment situation clearly, and look forward to a large number of new jobs brought by Greater Bay Area's economic construction in the future, [16] and seize employment opportunities in real time. In 2020, a large number of enterprises will enter the construction of Guangdong-Hong Kong-Macao Greater Bay Area, and the demand for jobs and talents with high technology, high skills and strong hands-on ability will soar. It is expected that the above "benefits" will greatly stimulate the enthusiasm of setting up higher vocational education colleges in Guangdong-Hong Kong-Macao Greater Bay Area, and also stimulate the enthusiasm of students who "have a skill" to apply for undergraduate and junior colleges of higher vocational education.

\section{References}

[1] Xie Hui, Jiang Dongqin. Research on existing problems and countermeasures of social service in higher vocational colleges [J]. Education modernization, 2017, 048: 352-354. 
[2] Yu Jinxiu, Zhou Ahong. Analysis on the current situation, causes and countermeasures of college students' employment difficulties [J]. Journal of huaihua university, 2010, 29 (12): 154-155.

[3] Li Junxiong. Countermeasures for Local Higher Vocational Colleges to Get out of the school-running dilemma-A Case study of Local Higher vocational Colleges in Hunan Province [D]. Hunan: Hunan Normal University, 2013.

[4] Cicc Qishin International Consulting Company. Vehicle maintenance and repair the project feasibility study report [EB/OL]. www.gtdcbgw.com, 2020/2020-07-25.

[5] Professional Training Program of Chongqing University [Z] Academic Affairs Office of Chongqing University, June 2014.

[6] zhaiyaohui, My Opinion on Integrated Teaching [j] Occupation, No. 18, 2011

[7] Bian Lili, Shao Zheng. Exploring ways to expand employment of Higher vocational Graduates-Taking JIANGSU Food Vocational And Technical College Employment Survey as an example [J]. Forum on Vocational Education, 2011 (29): 82-83.

[8] Liyu [J] Modern Vocational Education, No. 8 in 2019, October $30,2019$.

[9] Li Xiaofeng, give play to the supporting role of colleges and universities in the construction of Guangdong-Hong Kong-Macao Greater Bay Area [N] China Education News November 15, 2018.
[10] Education Department of Guangdong Province. Quality Report of Higher Vocational Education in Guangdong province in 2018 [M]. Guangdong: Guangdong Higher Education Press, 2018.

[11] Tang Lan. The average expected salary of 2018 graduates is 6,174 yuan $[\mathrm{EB} / \mathrm{OL}]$. www.xinhuanet.com, 2018-06-26/2020-07-25

[12] Jiang Lingfeng. 2018 national car ownership in 200 million for the first time a $[\mathrm{EB} / \mathrm{OL}$ ]. https://www.mps.gov.cn/n2254098/n4904352/c6354939/conte nt.html, 2019-01-12/2019-01-12.

[13] In-depth investigation and strategic consultation report of China's automobile maintenance market from 2018 to 2024 [j] 2018-9.

[14] China report hall. November 1, 2018 - the national foreign trade cargo throughput statistical analysis [EB/OL]. http://www.chinabgao.com/stat/stats/279081.html, 2018-12-20/2018-12-20.

[15] Dou Xiaoyong, LI Ying, GE Zhuxing. Theoretical Basis of Integrated Construction of Practical Training Platform for Deep Integration of Production and Education in Higher Vocational Colleges [J]. Think Tank Times, 2018, 148 (32): 133-135.

[16] Dong Yingshuai, Analysis of Employment Status and Problems of Higher Vocational College Students [J] Economic Management (Full Text Edition), October 01, 2016. 